\title{
A TUTELA PENAL DIFUSA NA PERSPECTIVA DA PROPRIEDADE INTELECTUAL
}

\section{THE CRIMINAL COURT DIFFUSES IN THE INTELLECTUAL PROPERTY PERSPECTIVE}

\section{DIOGO RAUSIS}

Advogado. Mestrando em Direito Empresarial e Cidadania pelo Centro Universitário Curitiba (UNICURITIBA), linha de pesquisa (2) Atividade Empresarial e Constituição: inclusão e sustentabilidade; Pós Graduado em Sociologia Política (Lato Sensu) pela Universidade Federal do Paraná - UFPR; Pós Graduado em História Contemporânea e Relações Internacionais (Lato Sensu) pela Pontifícia Universidade Católica do Paraná - PUC/PR; Pós Graduado em Relações Internacionais e Diplomacia (Lato Sensu) pelo Centro Universitário Curitiba (UNICURITIBA); Possui Graduação em Direito pela Faculdade de Direito de Curitiba (UNICURITIBA). E-mail:Diogo@rausis.adv.br

\section{RESUMO}

A importância da tutela do bem jurídico de natureza coletiva é debatida pela doutrina, por ela reconhecer que os bens a serem protegidos pela legislação penal não deveriam apenas possibilitar a coexistência dos indivíduos de forma estrita, mas sim, deveria haver uma proteção de cunho amplo e de forma imediata a fins sociais. Pela complexidade da conceituação dos bens jurídicos que deveriam ser tutelados, levando-se em consideração à própria complexidade que é a sociedade, pontuou-se que haveria as tutelas individuais e outras tutelas supra individuais, sendo aquela de interesses naturais do homem em sociedade (vida, patrimônio, cidadania etc.) e está 
Personalidade Acadêmica Homenageada:

Augustus B. Cochran III (Agnes Scott College)

sobre a sociedade como um todo frente aos interesses individuais, cujo Estado seria o portador dos direitos coletivos. Juristas vêm desenvolvendo a Teoria do Bem Jurídico com a perspectiva de uma tutela social, ficando cada vez mais a margem à concepção individualista dada pelo Direito Penal, passando-se a pensar em um sistema social de proteção, reconhecendo neste formato a complexidade da sociedade moderna. A sociedade moderna está inserida num sistema econômico globalizado, que fatores macroeconômicos, como o Mercado de Bens e Serviços, onde o nível de produção e exportação são fatores que determinam o crescimento econômico e sociocultural (dentro dos temas estudados na Macroeconomia, a Contabilidade Nacional é um método para listar a atividade econômica agregada de uma nação), devendo o Direito Penal posicionar-se sobre a proteção jurídica na esfera econômica.

PALAVRA-CHAVE: Teoria da Tutela Penal; Propriedade Intelectual; Funcionalismo Teleológico.

\section{REFERÊNCIAS}

AMARAL, Rentada Vargas. "Retaliação cruzada em propriedade intelectual: instrumento de efetivação do sistema de solução de controvérsias da Organização Mundial do Comércio (OMC)?". In: Pimentel, Luiz Otávio (org.). Eficiência Energética, Inovação e Propriedade Intelectual. Florianópolis: FUNJAB, 2013.

ARANTES NETO, Adelino. Responsabilidade do Estado no Direito Internacional e na OMC. 22a . ed. Curitiba: Ed. Juruá Editora,2007.

BIACCHI GOMES, Eduardo. Manual de Direito da Integração Regional. 2ª . ed. Curitiba: Ed. Juruá Editora,2012.

CRUCINI, Mario J; Kahn, James. Tariffs and aggregate economic activity: lessons from the great depression. Journal of Monetary Economics. Ed. Elserver. V. 38. Issue $\quad 3, \quad 1996, P . \quad 246 \quad-\quad$ 467.Disponível em: <http://www.sciencedirect.com/science/article/pii/S0304393296012986>. Acesso em: 27/07/2014.

DUPUY, Pierre-Marie. Le Fait Générateur de La Responsabilité Internationale 
Personalidade Acadêmica Homenageada:

Augustus B. Cochran III (Agnes Scott College)

des États. RCADI, v.188,1984. p.9-134.

GANDELMAN, Maria. 1‥ ed. Poder e Conhecimento na Economia Global: O Regime Internacional da Propriedade Intelectual da Sua Formação às Regras de Comércio Atuais. Rio de Janeiro: Ed. Civilização Brasileira, 2004.

GONÇALVES, Reinaldo; Baumann, Renato; Canuto, Otaviano; C. D. Prado, Luiz. A Nova Economia Internacional: Uma Perspectiva Brasileira. 9‥ ed. Rio de Janeiro: Ed. Campus, 1998.

INSTITUTO NACIONAL DA PROPRIEDADE INTELECTUAL. Apresenta o Decreto na 1. 355, de dezembro de 1994, cujo apenso trás o Acordo Sobre Aspectos dos Direitos de Propriedade Intelectual Relacionados ao Comércio. Disponível em: <www.inpi.gov.br/images/stories/27-trips-portugues1.pdf>. Acesso em: $15 / 08 / 2014$.

JESCHECK, Hans-Heinrich. Tratado de derecho penal: parte general. 4. ed. Trad. JoséLuis ManzanaresSamaniego. Granada: Comares, 1993.

MIR PUIG, Santiago. Derecho penal: parte general. 5.ed. Barcelona: Reppertor, 1998.

NUNES, Rizzato. Curso de direito do consumidor. São Paulo: Saraiva, 2004, p. 55.

PERELMAN, Chaim. Ética e Direito. São Paulo: Martins Fontes, 1999, p. 400.

ROXIN, Claus. Por Uma Proibição de Valorar a Prova Nos Casos de Omissão Do Dever De Informação Qualificada. Revista Jurídica. Curitiba, n.24 v.1. p.143152,2010 .

TACHINARDI, Maria Helena. A Guerra das Patentes: Conflito Brasil x EUA sobre propriedade intelectual. 1ª ed. São Pauli: Ed. Paz e Terra, 1993. 